\title{
The clinical implication of SS18-SSX fusion gene in synovial sarcoma
}

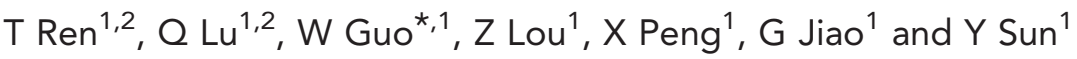 \\ ${ }^{1}$ Musculoskeletal Tumor Center, Peking University People's Hospital, Beijing 100044, China
}

Background: The aim of this study is to evaluate distribution and clinical impact of the SS18-SSX fusion gene in patients with synovial sarcoma in China.

Methods: We collected and analysed the clinical data of 88 patients using univariate and multivariate survival analysis. HEK 293T and NIH 3T3 cell lines were transfected with the SS18-SSX1 or SS18-SSX2 gene to determine the respective involvement of these fusion genes in cell proliferation and invasion.

Results: Overall survival was significantly better among SS18-SSX2 cases $(P=0.001)$, FNCLCC grade 2 cases $(P<0.001)$, and UICC stage 1 or $2(P<0.001)$ by univariate and multivariate survival analysis. SS18-SSX1-positive cells were more proliferative and invasive than SS18-SSX2-positive cells.

Conclusion: SS18-SSX fusion type is a significant prognostic factor for patients with synovial sarcoma.

Synovial sarcoma (SS), an aggressive soft tissue sarcoma, occurs at any age but often in young adults and has a predilection for the extremities (Kransdorf, 1995). This tumour accounts for $10 \%$ of all soft tissue sarcomas. According to the presence or absence of welldeveloped glandular epithelial cells, SS can be divided into two major histological types: monophasic and biphasic. More than a quarter of patients succumb to this tumour in the first 5 years after diagnosis, despite the best currently available management (Lewis and Brennan, 1996; Lewis et al, 2000).

Cytogenetically, more than $95 \%$ of SS is characterised by the $\mathrm{t}(\mathrm{X} ; 18)$ (p11.2; q11.2) chromosomal translocation, which always represents the fusion of SS18 with either SSX1 or SSX2, or rarely with SSX4 (Ladanyi, 1995; dos Santos et al, 2001; Ladanyi, 2001). The SS18-SSX1 and SS18-SSX2 fusion genes appear to be mutually exclusive in SS, and the fusion type is concordant in primary tumours and metastases and constant over the development of disease (Panagopoulos et al, 2001). Detection of the SS18-SSX fusion gene with reverse-transcriptase polymerase chain reaction (RT-PCR) has been used as a sensitive diagnostic method for SS (van de Rijn et al, 1999; Guillou et al, 2001; Ladanyi, 2001). Although the function of this fusion gene is largely unknown, it is considered to have a critical role in oncogenesis and development of SS (dos Santos et al, 2001; Ladanyi, 2001). Its inhibition by small interfering RNA can block the proliferation and migration of SS cells (Peng et al, 2008; Takenaka et al, 2010).

The clinical impact of this fusion gene has been described in many papers but remains debated. Kawai et al (1998) first reported that patients with the SS18-SSX1 fusion gene had a significantly worse outcome than patients with SS18-SSX2 fusion gene, and others found the same result (Nilsson et al, 1999; Inagaki et al, 2000; Mezzelani et al, 2001; Panagopoulos et al, 2001; Ladanyi et al, 2002; Sun et al, 2009). However, some findings indicated that the SS18-SSX fusion gene variants were not prognostically important in patients with SS (Guillou et al, 2004; Takenaka et al, 2008). Moreover, the frequency of the two types might vary geographically in these patients (Koković et al, 2004).

Here we wanted to clarify the distribution and prognostic value of the SS18-SSX fusion gene in Chinese patients with SS and investigated its involvement in cell proliferation and invasion.

\section{MATERIALS AND METHODS}

Patients. After approval by Institutional Review Boards of Peking University People's Hospital (No. 0016781), consecutive SS cases at

*Correspondence: Dr W Guo, E-mail: guowei_bonetumor@163.com
${ }^{2}$ These authors contributed equally to this work.

Received 7 June 2013; revised 16 August 2013; accepted 16 August 2013; published online 10 September 2013

(c) 2013 Cancer Research UK. All rights reserved 0007-0920/13 
the Peking University People's Hospital from January 2000 and January 2012 were identified and reviewed retrospectively. Informed consent for the experimental use of surgical specimens was obtained from all patients in written form according to the hospital's ethical guidelines. Data included patient age at diagnosis, sex, tumour size, tumour site, surgery modality, histological type, histological grade using the Fédération Nationale des Centers de Lutte Contre le Cancer (FNCLCC) grading system (Guillou et al, 1997), and disease stage according to the International Union Against Cancer (UICC)/American Joint Committee on Cancer (AJCC) staging system (Sobin and Wittekind, 1997). Histological subtyping was performed on hematoxylin and eosin-stained sections, using the 2002 World Health Organization classification of tumours of soft tissue and bone (Fletcher et al, 2002), and cases were divided into monophasic and biphasic categories. Amputation was included in wide excision. Tumour sites were divided into extremity (neoplasms of extremity only) and the trunk (including the pelvis, shoulder, inguinal region, and axillary region).

Cell culture and SS18-SSX fusion gene transfection. HEK 293T and NIH 3T3 cell lines obtained from the ATCC (American Type Culture Collection, Manassas, VA, USA) were grown in Dulbecco's modified Eagle's medium (DMEM, Gibco, NY, USA) supplemented with $10 \%$ fetal bovine serum (FBS, Gibco) and $10 \%$ bovine calf serum (BCS, Gibco), respectively. Cells were maintained at $37^{\circ} \mathrm{C}$ in a humidified atmosphere with $5 \% \mathrm{CO}_{2}$. Full-length human SS18-SSX1 (RefSeq: NM_ 001007559.1) or SS18-SSX2 (RefSeq: NM_ 005637.2) cDNA was inserted into the eukaryotic vector pCMV6-AC-GFP separately (purchased from OriGene Technologies, Inc., Cat. No: RG219498 and RG215192, respectively). 293T cells were transfected with the recombinant plasmids and vector alone (mock transfectants) using Lipofectamine 2000 reagent (Life Technologies, Carlsbad, CA, USA) as described by the manufacturer and cultured in DMEM supplemented with 10\% FBS and $800 \mu \mathrm{g} \mathrm{ml}^{-1}$ G418 (AMRESCO, OH, USA). 3T3 cells were transfected as described above but cultured in DMEM supplemented with $10 \%$ BCS and $250 \mu \mathrm{g} \mathrm{ml}^{-1} \mathrm{G} 418$.

RNA isolation and RT-PCR. Total RNA was extracted from cells and frozen tumour fragments from all patients with SS using TRIzol reagent (Invitrogen, La Jolla, CA, USA) according to the manufacturer's protocol. Total RNA $(2 \mu \mathrm{g})$ was used for the reverse transcription with the cDNA Reverse Transcription kit (Invitrogen), following the manufacturer's instructions. The detection of SS18-SSX1 cDNA was performed by RT-PCR with the forward primer $5^{\prime}$-CAGGGCTACGGTCCTTCACA- $3^{\prime}$ and reverse primer $5^{\prime}$-GGTGCAGTTGTTTCCCATCG- $3^{\prime}$. The identification of SS18-SSX2 CDNA was performed by RT-PCR with the forward primer $5^{\prime}$-GACCACCTCCACAACAGGGAT- $3^{\prime}$ and reverse primer $5^{\prime}$-GGCACAGCTCTTTCCCATCA- $3^{\prime}$. The amplification profile of the PCR consisted of 40 cycles of denaturation at $94{ }^{\circ} \mathrm{C}$ for $50 \mathrm{~s}$, annealing at $58^{\circ} \mathrm{C}$ for $30 \mathrm{~s}$, and extension at $72{ }^{\circ} \mathrm{C}$ for $1 \mathrm{~min}$. Glyceraldehyde-3-phosphate dehydrogenase $(\mathrm{GAPDH})$ was used as an internal control, with the forward primer $5^{\prime}$-TGGGCTACACTGAGCACCAG- $3^{\prime}$ and reverse primer $5^{\prime}$-AAGTGGTCGTTGAGGGCAAT- $3^{\prime}$ and was synthesised on the basis of the human GAPDH mRNA sequence (GenBank Accession No. BC013310). cDNA replaced with water is used as a negative control. The PCR products were analysed by electrophoresis on $1.5 \%$ agarose gels.

Cell proliferation assay. Cell proliferation was determined using the 3-(4, 5-dimethylthiazol-2-yl)-2, 5-diphenyltetrazolium bromide assay. The cells were trypsinised, and $5 \times 10^{3}$ cells per well were seeded into 96 -well plates in triplicate. Cellular proliferation was determined once per day during the 5-day period. In brief, $20 \mu \mathrm{l}$ MTT ( $5 \mathrm{mg} \mathrm{ml}^{-1}$ in phosphate-buffered saline) was added to each well, and the cells were incubated at $37^{\circ} \mathrm{C}$ in a humidified atmosphere containing 5\% $\mathrm{CO}_{2}$. Cells were lysed after 4-6 h using cell lysis reagent (20\% sodium dodecyl sulphate, $50 \%$ dimethylsulphoxide, $\mathrm{pH} 4.7$ ), and absorbency was measured at $570 \mathrm{~nm}$ with an EL-311SX enzyme-linked immunosorbent assay reader (Bio-Tek Instruments, Winooski, VT, USA). This experiment was replicated three times.

In vitro migration and invasion assays. Migration and invasion assays were performed by seeding $3 \times 10^{5}$ cells in $200 \mu \mathrm{l}$ DMEM on top of transwell cell culture inserts containing a polyethylene terephthalate membrane pre-coated with or without Matrigel (24-well inserts, $8.0-\mu \mathrm{m}$ pore size; Coster, Corning Inc., Corning, NY, USA). The lower chamber was filled with $0.8 \mathrm{ml}$ DMEM with $10 \%$ FBS for $293 \mathrm{~T}$ cells and $10 \%$ BCS for $3 \mathrm{~T} 3$ cells. After incubation for $24 \mathrm{~h}$, the non-migrating cells were scraped off, and the membranes were fixed and stained using the Diff-Quik stain kit (Sysmex Co., Hyogo, Japan). Cells that had migrated through the membranes were quantified by determination of the cell number in nine randomly chosen visual fields at $\times 200$ magnification. This experiment was replicated three times.

Statistical analysis. The results of proliferation, migration, and invasion assays were presented as the mean \pm s.e. The analysis of their differences was performed using $t$-tests and analysis of variance (ANOVA). The following variables were considered for the prognostic value: age at diagnosis, sex, tumour size, tumour site (extremity and trunk), surgery modality (wide and marginal excision), histological type, FNCLCC system, UICC system, and SS18-SSX fusion type. Associations of SS18-SSX fusion type and other prognostic values were analysed using the two-sided Pearson $\chi^{2}$-test. Survival curves were estimated by the Kaplan-Meier method and analysed by the log-rank test. Multivariate analyses on the basis of the stepwise Cox proportional hazards model were used to identify the most significant factors related to overall survival (OS). All statistical analyses were performed with the SPSS statistical software package 13.0 (SPSS, Inc., Chicago, IL, USA). All two-sided $P$-values $<0.05$ were considered statistically significant.

\section{RESULTS}

Patients and tumour characteristics. In our series, 47 (51.1\%) and $41(44.6 \%)$ patients were detected to have the SS18-SSX1 and SS18-SSX2 fusion genes, respectively (Figure 1). Four patients $(4.3 \%)$ were found not to have either of the fusion genes. Among the 88 patients with SS and the SS18-SSX fusion gene, 56 were men $(63.6 \%)$ and 32 were women (36.4\%). The mean age at diagnosis was 33 years, ranging from 11 to 58 years. A total of 54 tumours were located in an extremity (24 upper limbs and 30 lower limbs), 34 were truncal, including the shoulder $(n=7)$, pelvis $(n=16)$,

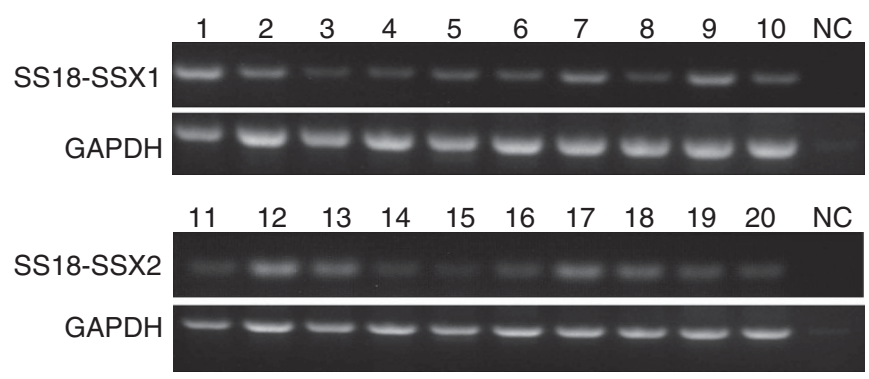

Figure 1. The electrophoresis image of RT-PCR products of fusion gene. The images of ten SS18-SSX1-and SS18-SSX2-positive patients were shown in the higher and lower panels separately. cDNA replaced with water is used as a negative control (NC). 
spine $(n=9)$, and axillary regions $(n=2)$. Fifty-one tumours were smaller than $5 \mathrm{~cm}$ and thirty-seven were $5 \mathrm{~cm}$ or larger. The 88 tumours were histologically classified as either monophasic SS $(n=50,56.8 \%)$ or biphasic SS $(n=38,43.2 \%)$. For histological grade, $53(60.2 \%)$ and $35(39.8 \%)$ patients had grades 2 and 3 , respectively. According to the UICC staging system, 50 (56.8\%) and 38 patients $(43.2 \%)$ were classified as having stage $1 / 2$ and stage $3 / 4$, respectively. Surgery modality for 88 patients included wide excision ( $n=57$, including 16 amputations) and marginal excision $(n=31)$. A total of $24(27.3 \%)$ and 21 patients $(23.9 \%)$ were given preoperative or postoperative radiotherapy and chemotherapy, respectively.

The mean follow-up time was 42.7 months, with a range from 12 to 110 months. Forty-nine patients (55.7\%) died of their malignancy. Forty-four patients (50\%) experienced a local recurrence, and twenty-eight (31.9\%) had metastasis. Among patients with recurrence, eight had a second recurrence, and four had at least a third recurrence. The metastatic location included the lung $(n=20)$, bone $(n=3)$, pleura $(n=4)$, brain $(n=2)$, and lymph node $(n=2)$. Three patients developed multiple metastases.

Association between SS18-SSX fusion type and other prognostic factors. Table 1 shows the associations between SS18-SSX fusion type and other factors. A significant association between histological type and SS18-SSX fusion type was observed $(P=0.001)$. Tumours $(n=47)$ expressing SS18-SSX1 fusion

Table 1. Relationship between SS18-SSX fusion type and other factors

\begin{tabular}{|c|c|c|c|c|}
\hline \multicolumn{5}{|c|}{ Fusion gene } \\
\hline Factor & SSS18-SSX1 & SS18-SSX2 & $\chi^{2}$ & $\boldsymbol{P}$-value \\
\hline Age & & & 2.331 & 0.127 \\
\hline$<33$ & 21 & 25 & & \\
\hline$\geqslant 33$ & 26 & 16 & & \\
\hline Sex & & & 1.67 & 0.196 \\
\hline Male & 27 & 29 & & \\
\hline Female & 20 & 12 & & \\
\hline Size & & & 4.303 & 0.038 \\
\hline$<5 \mathrm{CM}$ & 23 & 28 & & \\
\hline$\geqslant 5 \mathrm{CM}$ & 24 & 13 & & \\
\hline Histological type & & & 11.049 & 0.001 \\
\hline MSS & 19 & 31 & & \\
\hline BSS & 28 & 10 & & \\
\hline Site & & & 2.842 & 0.092 \\
\hline Extremity & 25 & 29 & & \\
\hline Trunk & 22 & 12 & & \\
\hline FNCLCC grade & & & 1.014 & 0.314 \\
\hline 2 & 26 & 27 & & \\
\hline 3 & 21 & 14 & & \\
\hline UICC stage & & & 0.541 & 0.462 \\
\hline 1 or 2 & 25 & 25 & & \\
\hline 3 or 4 & 22 & 16 & & \\
\hline Surgery modality & & & 0.39 & 0.843 \\
\hline Wide excision & 30 & 27 & & \\
\hline Marginal excision & 17 & 14 & & \\
\hline
\end{tabular}

transcripts were monophasic $(n=19)$ and biphasic $(n=28)$; tumours $(n=41)$ expressing SS18-SSX2 fusion transcripts were almost wholly monophasic $(n=31)$ except for 10 biphasic SS cases.

Tumour size $(<5 \mathrm{~cm}$ or $\geqslant 5 \mathrm{~cm})$ was significantly associated with SS18-SSX fusion type $(P=0.038)$. For SS with SS18-SSX2 fusion transcripts, there were 28 tumours $(68.3 \%)$ smaller than $5 \mathrm{~cm}$. SS18-SSX fusion type was not significantly associated with age at diagnosis, sex, tumour site (extremity and trunk), surgery modality (wide and marginal excision), FNCLCC grade, or UICC stage (all $P>0.05$ ).

Survival analysis. OS was significantly better among SS18-SSX2 cases $(P=0.001)$, cases of tumours smaller than $5 \mathrm{~cm}(P<0.001)$, cases involving patients younger than 33 years $(P=0.018)$, FNCLCC grade 2 cases $(P<0.001)$, and UICC stage 1 or 2 $(P<0.001)$ (Figure 2). However, sex, tumour site, histological type, radiotherapy, chemotherapy, and surgery modality had no impact on OS (Table 2).

Cox regression identified that the SS18-SSX1 fusion type $(\mathrm{RR}=2.343 ; P=0.002)$, aggressive $\mathrm{FNCLCC}$ grade $3(\mathrm{RR}=$ 2.478; $P=0.006)$, and UICC stage 3 or $4(\mathrm{RR}=3.379 ; P=0.001)$ were the independently negatively predictive factors of OS (Table 3).

SS18-SSX1 but not SS18-SSX2 associated with cell proliferation, migration, and invasion. Having shown that SS18-SSX1 expression was associated with poorer OS than SS18-SSX2, we examined the molecular mechanism involved. 293T and 3T3 cells were transfected with plasmid DNA encoding the full-length SS18-SSX1 or SS18-SSX2. After G418 screening for several weeks, stable transfected cell lines expressing SS18-SSX1 and SS18-SSX2 were established. RT-PCR was used to identify the expression (Figure 3).

Next, we examined differences in the proliferation of SS18-SSX1 and SS18-SSX2 genes using MTT assays for stable transfectants. Cell proliferation was significantly promoted in cells transfected with the SS18-SSX1 gene compared with cells transfected with the SS18-SSX2 gene (Figure 4).

We evaluated the different effects of the SS18-SSX1 and SS18SSX2 genes on migration and invasion using the Boyden chamber. Migration and invasion were significantly enhanced by SS18-SSX1 transfectants compared with SS18-SSX2 transfectants (Figure 5).

\section{DISCUSSION}

SS characterised by SS18-SSX fusion transcripts is an aggressive soft tissue sarcoma (Guillou et al, 1997; Kawai et al, 1998; Lewis et al, 2000). The aim of this present study was to identify the clinical impact of SS18-SSX fusion type in SS and the mechanism involved. Of the 92 patients analysed by PT-PCR, 88 were positive for a SS18-SSX fusion transcript, which is in accordance with the literature (Ladanyi, 1995, 2001; Panagopoulos et al, 2001). Only four patients were not identified as positive for a fusion gene, and these cases were excluded from the analysis. The ratio of SS18SSX1 and SS18-SSX2 has been about 2:1 in the majority of studies (Guillou et al, 2001; Panagopoulos et al, 2001; Ladanyi et al, 2002; Takenaka et al, 2008); however, Sun et al (2009) reported that the ratio is close to $1: 2$ in Chinese patients with SS. In the present study, the ratio of SS18-SSX1 and SS18-SSX2 was close to 1:1, in agreement with another previous report (Inagaki et al, 2000). Geographic differences in distribution of SS18-SSX genes may explain these discrepancies.

The associations of SS18-SSX fusion type and other clinicopathological parameters were analysed in the study. Many authors have observed that major biphasic SS contain the SS18-SSX1 fusion transcript and that monophasic SS mostly express the SS18-SSX2 fusion transcript (Kawai et al, 1998; Ladanyi et al, 2002; Takenaka 
A

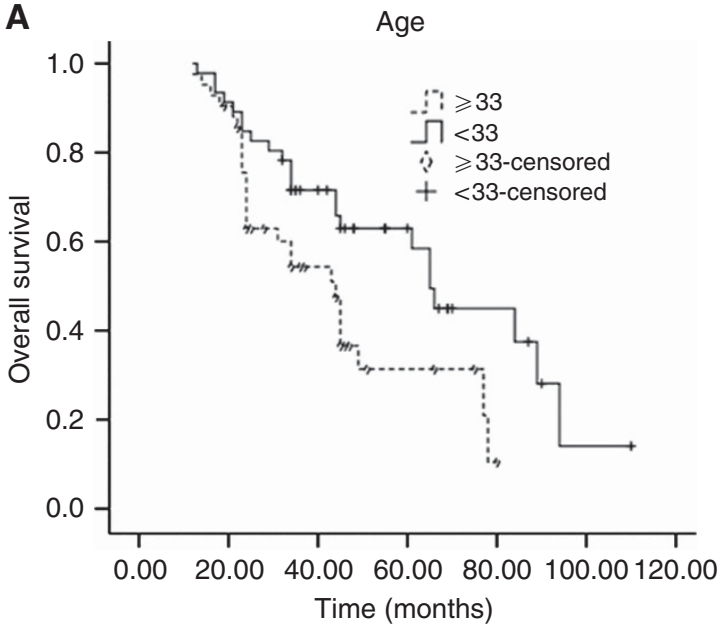

C

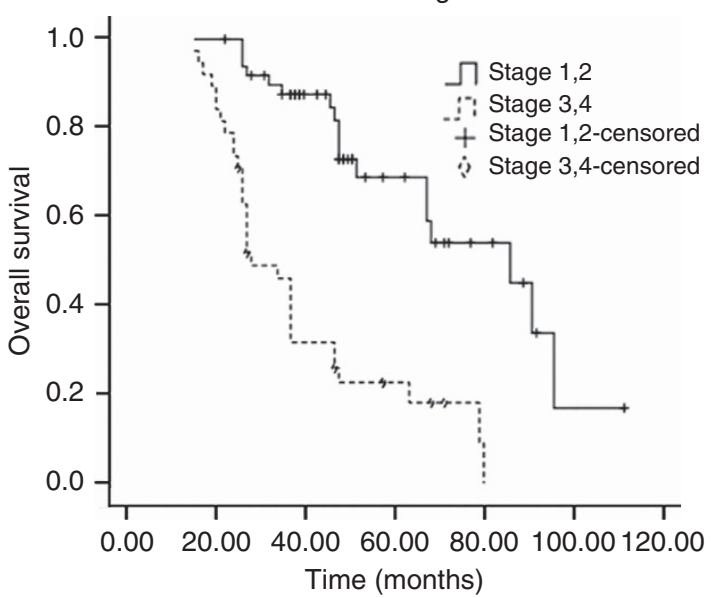

E

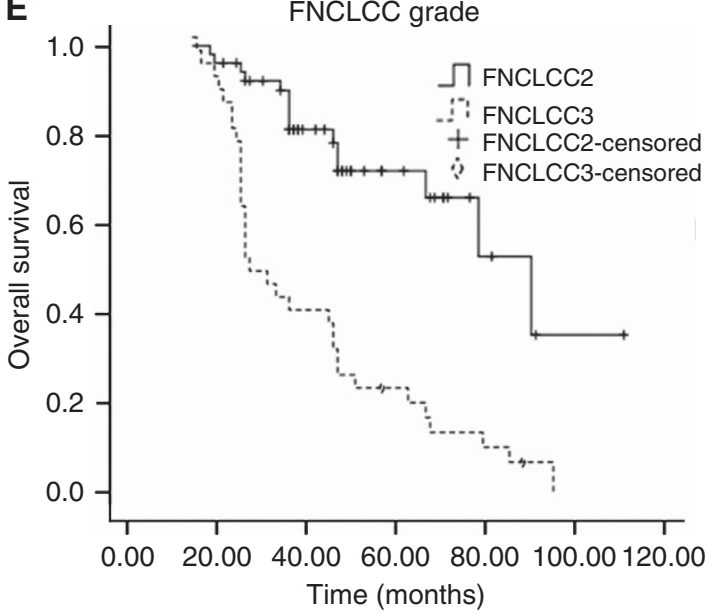

B

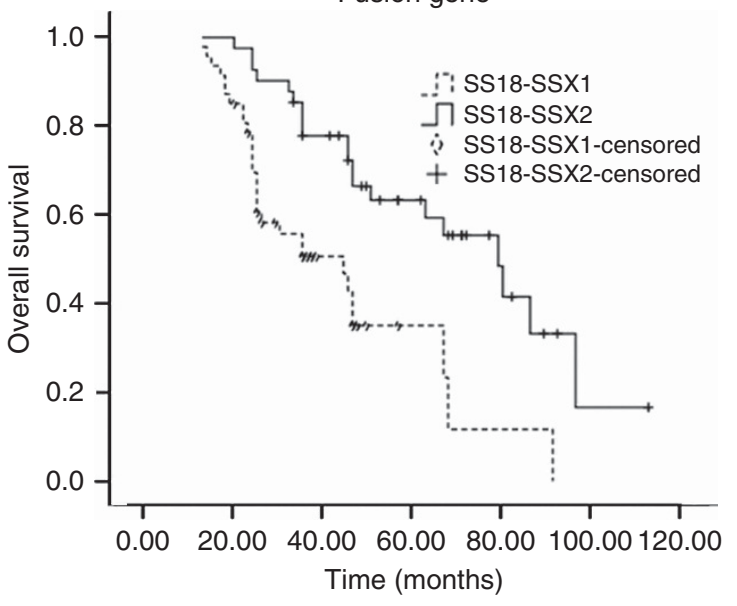

D
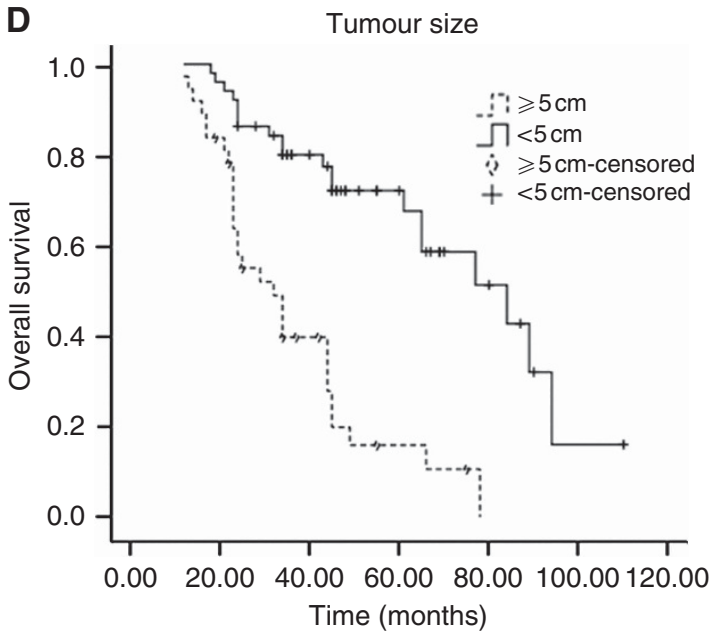

Figure 2. The curves of overall survival according to $(\mathbf{A})$ age at diagnosis, $P=0.018 ;(\mathbf{B})$ fusion gene type, $P=0.001 ;(\mathbf{C})$ International Union Against Cancer stage, $P<0.01$; (D) tumour size, $P<0.01$; (E) Fédération Nationale des Centers de Lutte Contre le Cancer grade, $P<0.01$ in 88 patients with synovial sarcoma.

et al, 2008; Sun et al, 2009). We also found that SS18-SSX2 fusion transcript was rarely observed in biphasic SS $(P=0.001)$. Moreover, this series also revealed a statistically significant association between the fusion type and tumour size $(P=0.038)$. Guillou et al (2004) have found that SS18-SSX1-positive tumours tended to be smaller $(<7 \mathrm{~cm})$ than $\mathrm{SS} 18$-SSX2-positive tumours, but when they divided tumour sizes at a $5 \mathrm{~cm}$ cutoff, there was no significant difference. However, our results demonstrated that SS18-SSX2-positive tumours tended to be smaller than $5 \mathrm{~cm}(P=0.038)$. This association between the fusion type and tumour size has not been noted previously, and the MTT results further revealed that the SS18SSX1-positive cells displayed more proliferative potential than 


\begin{tabular}{|c|c|c|c|}
\hline Factor & $\begin{array}{l}\text { No. of } \\
\text { patients }\end{array}$ & $\begin{array}{c}\text { 5-year } \\
\text { overall } \\
\text { survival (\%) }\end{array}$ & $\begin{array}{c}P \text {-value } \\
\text { (log-rank } \\
\text { tests) }\end{array}$ \\
\hline Age & & & 0.018 \\
\hline $\begin{array}{l}<33 \\
\geqslant 33\end{array}$ & $\begin{array}{l}46 \\
42\end{array}$ & $\begin{array}{l}63 \\
31.4\end{array}$ & \\
\hline Sex & & & 0.408 \\
\hline $\begin{array}{l}\text { Male } \\
\text { Female }\end{array}$ & $\begin{array}{l}56 \\
32\end{array}$ & $\begin{array}{l}51.7 \\
46.1\end{array}$ & \\
\hline Size & & & $<0.01$ \\
\hline $\begin{array}{l}<5 \mathrm{CM} \\
\geqslant 5 \mathrm{CM}\end{array}$ & $\begin{array}{l}51 \\
37\end{array}$ & $\begin{array}{l}72.1 \\
15.9\end{array}$ & \\
\hline Histological type & & & 0.193 \\
\hline $\begin{array}{l}\text { MSS } \\
\text { BSS }\end{array}$ & $\begin{array}{l}50 \\
38\end{array}$ & $\begin{array}{l}41.4 \\
57.8\end{array}$ & \\
\hline Site & & & 0.05 \\
\hline $\begin{array}{l}\text { Extremity } \\
\text { Trunk }\end{array}$ & $\begin{array}{l}54 \\
34\end{array}$ & $\begin{array}{l}58.2 \\
36.1\end{array}$ & \\
\hline FNCLCC grade & & & $<0.01$ \\
\hline $\begin{array}{l}2 \\
3\end{array}$ & $\begin{array}{l}53 \\
35\end{array}$ & $\begin{array}{l}70.6 \\
22.9\end{array}$ & \\
\hline UICC stage & & & $<0.01$ \\
\hline $\begin{array}{l}1 \text { or } 2 \\
3 \text { or } 4\end{array}$ & $\begin{array}{l}50 \\
38\end{array}$ & $\begin{array}{l}68.9 \\
22.7\end{array}$ & \\
\hline Fusion gene & & & 0.01 \\
\hline $\begin{array}{l}\text { SS18-SSX1 } \\
\text { SS18-SSX2 }\end{array}$ & $\begin{array}{l}47 \\
41\end{array}$ & $\begin{array}{l}35.1 \\
63.3\end{array}$ & \\
\hline Surgery modality & & & 0.5 \\
\hline $\begin{array}{l}\text { Wide excision } \\
\text { Radical excision }\end{array}$ & $\begin{array}{l}57 \\
31\end{array}$ & $\begin{array}{l}53.3 \\
41.5\end{array}$ & \\
\hline Radiotherapy & & & 0.056 \\
\hline $\begin{array}{l}\text { No } \\
\text { Yes }\end{array}$ & $\begin{array}{l}64 \\
24\end{array}$ & $\begin{array}{l}21.5 \\
37.5\end{array}$ & \\
\hline Chemotherapy & & & 0.143 \\
\hline $\begin{array}{l}\text { No } \\
\text { Yes }\end{array}$ & $\begin{array}{l}67 \\
21\end{array}$ & $\begin{array}{l}44.4 \\
49.8\end{array}$ & \\
\hline \multicolumn{4}{|c|}{$\begin{array}{l}\text { Abbreviations: BSS = biphasic synovial sarcoma; FNCLCC }=\text { Fédération Nationale des } \\
\text { Centers de Lutte Contre le Cancer; MSS =monophasic synovial sarcoma; UICC = } \\
\text { International Union Against Cancer. }\end{array}$} \\
\hline
\end{tabular}

SS18-SSX2-positive cells. Takenaka et al (2008) reported that tumours with the SS18-SSX1 fusion transcript were always located in the extremities, whereas tumours with the SS18-SSX2 fusion transcript were equally distributed between extremities and the trunk. The association of SS18-SSX fusion type and tumour location in the present series was the reverse but not statistically significantly different.

The prognostic implication of SS18-SSX fusion type in SS has been reported in many papers, but the results are mixed. We found that patients with SS18-SSX1-positive tumours had substantially shorter OS than those with SS18-SSX2-positive tumours. In addition, SS18-SSX1-positive tumours showed a significant association with worse clinical outcome in univariate analysis and retained a significant factor for OS after adjustment for other prognostic factors in multivariate analysis, in accordance with a previous report in a Chinese population (Sun et al, 2009). Tumour invasion of the bone, nerve, or vascular structures is an independent adverse prognostic factor for SS (Guillou et al, 2004).
Table 3. Multivariate analysis for 5-year overall survival with patient and tumour characteristics

\begin{tabular}{|c|c|c|c|}
\hline & \multicolumn{2}{|c|}{ Overall survival } & $P$-value \\
\hline Variable & $\begin{array}{l}\text { Risk } \\
\text { ratio }\end{array}$ & $\begin{array}{l}95 \% \text { confidence } \\
\text { interval }\end{array}$ & $\begin{array}{c}\text { Cox multivariate } \\
\text { analysis }\end{array}$ \\
\hline SS18-SSX1/SS18-SSX2 & 2.343 & $2.177-2.667$ & 0.002 \\
\hline FNCLCC grade $2 / 3$ & 2.478 & $1.291-4.775$ & 0.006 \\
\hline UICC stage $1,2 / 3,4$ & 3.379 & $1.651-6.917$ & 0.001 \\
\hline
\end{tabular}

Abbreviations: FNCLCC $=$ Fédération Nationale des Centers de Lutte Contre le Cancer $\mathrm{UICC}=$ International Union Against Cancer

Our results also demonstrated that the cells with the SS18-SSX1 type behaved more invasively than those with the SS18-SSX2 gene. The proliferation, migration, and invasion capacities of the SS18SSX1-positive cells were much higher than in the SS18-SSX2positive cells.

The prognostic value of histological type has been controversial. In earlier studies, patients with biphasic SS tumours had better outcomes (Krall et al, 1981; Cagle et al, 1987). However, recent studies, including ours, identified no difference in OS between patients with monophasic and biphasic SS tumours (Kawai et al, 1998; Lewis et al, 2000; Spillane et al, 2000; Mezzelani et al, 2001; Ladanyi et al, 2002; Guillou et al, 2004; Koković et al, 2004; Sun et al, 2009). According to the FNCLCC grade, SS was divided into two groups: low grade (grade 2) and high grade (grade 3) (Guillou et al, 1997). The UICC stage was established according to histological grade, tumour size, lymph node metastasis, and distant metastasis, and we divided the cases into two groups on the basis of this system: stage $1 / 2$ and stage $3 / 4$. In this series, high histological grade and UICC stage were important and independent adverse predictors for OS, in keeping with other reports (Guillou et al, 2004; Koković et al, 2004; Sun et al, 2009).

Moreover, our results demonstrated that small tumour size $(<5 \mathrm{~cm})$ was associated with a relatively favourable outcome but was not an independent predictor for OS. Larger tumour size has been identified as a negative clinical predictor and classified variously as $5 \mathrm{~cm}$ (Spillane et al, 2000; Guillou et al, 2004; Sun et al, 2009), $7 \mathrm{~cm}$ (Guillou et al, 2004), and $8 \mathrm{~cm}$ (Trassard et al, 2001). We chose $5 \mathrm{~cm}$ as the cutoff point because it was used in the UICC/ AJCC staging system (Sobin WC, 1997), and many reports have reported a tumour size of $5 \mathrm{~cm}$ or more to be a negative prognostic factor (Kawai et al, 1998; Bergh et al, 1999; Machen et al, 1999; Lewis et al, 2000; Spillane et al, 2000).

Generally, younger patient age has been commonly noted as a significantly positive clinical prognostic factor. We chose the mean age at diagnosis (33 years) as the cutoff point and found a strong association between death from malignances and age greater than 33 years. This result is in keeping with some previous reports (Bergh et al, 1999; Guillou et al, 2004; Sun et al, 2009); however, Spillane et al found that younger age was associated with a poor prognosis. Furthermore, a multi-institutional analysis yielded no correlation between age at diagnosis and prognosis of patients (Ladanyi et al, 2002).

The role of chemotherapy and radiotherapy in the treatment of SS is also controversial (Mullen \& Zagars, 1994; Bergh et al, 1999; Trassard et al, 2001; Brecht et al, 2006; Takenaka et al, 2008). In our series, $24(27.3 \%)$ and 21 patients (23.9\%) were given preoperative or postoperative radiotherapy and chemotherapy, respectively, in a non-randomised manner. There was no evidence of an OS benefit for chemotherapy and radiotherapy in this group.

In conclusion, these results show that SS18-SSX1 and SS18-SSX2 can serve as potential independent prognostic factors for OS in 

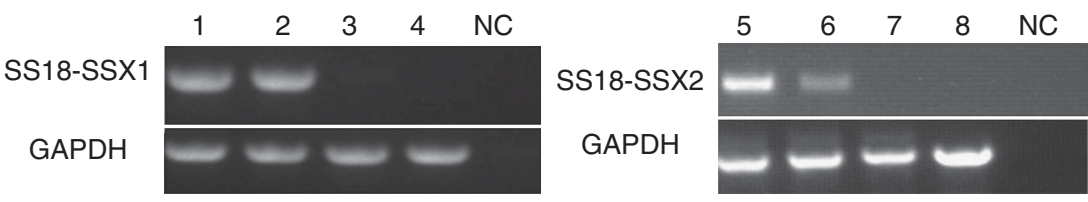

Figure 3. The electrophoresis image of RT-PCR products of cells transfected with the recombinant plasmids. 1 and 5 represent $293 T$ cells transfected with SS18-SSX1 and SS18-SSX2 separately; 2 and 6 represent 3T3 cells transfected with SS18-SSX1 and SS18-SSX2 separately; 3 and 7 represent 293T cells transfected with vector to detect SS18-SSX1 and SS18-SSX2 separately; 4 and 8 represent 3T3 cells transfected with vector to detect SS18-SSX1 and SS18-SSX2 separately.CDNA replaced with water is used as a negative control (NC).
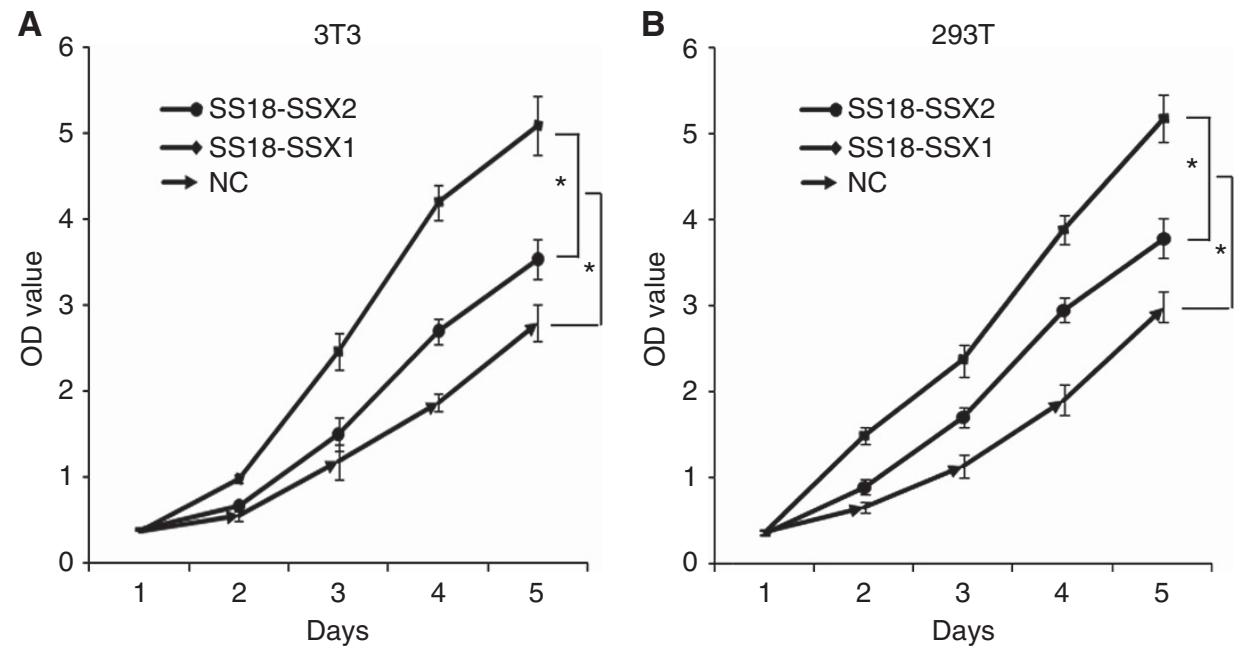

Figure 4. Overexpression of SS18-SSX1 promoted cell proliferation than SS18-SSX2. 3T3 and 293T cells were stably transfected with SS18-SSX1, vector, and SS18-SSX2 separately. Cell proliferation was assessed using MTT assays. 3T3 (A) and 293T (B) cells with SS18-SSX1 were more proliferative during 5-day period. The cells transfected with vector alone worked as a negative control (NC). This experiment was replicated three times.

A

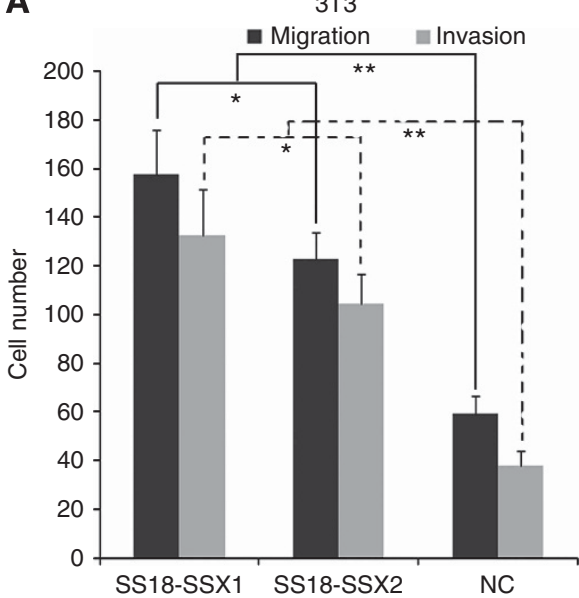

B

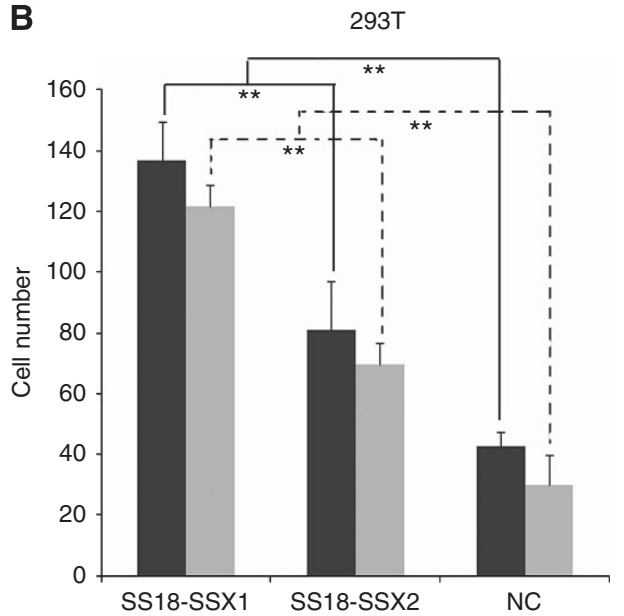

Figure 5. Cells with SS18-SSX1 showed more invasion and migration potential. 3T3 and 293T cells were stably transfected with SS18-SSX1, vector, and SS18-SSX2. Cell invasion and migration assay was assessed by Transwell cell culture with or without Matrigel. Cells that had migrated through the membranes were quantified by determination of the cell number in nine randomly chosen visual fields at $\times 200$ magnification. Average number of invasive or migratory cell number per field from three independent experiments + s.e. is at top. 3T3 (A) and 293T (B) cell invasion and migration were significantly enhanced by SS18-SSX1 gene $\left({ }^{*} P<0.05,{ }^{\star} P<0.01\right)$. The cells transfected with vector alone is used as a negative control (NC). This experiment was replicated three times.

patients with SS. In addition, SS18-SSX1-positive cells show more invasive tendencies than those that are SS18-SSX2 positive.

\section{ACKNOWLEDGEMENTS}

This work was financially supported by Grants from the National Natural Science Foundation of China (Grant No. 81001193), and the Specialised Research Fund for the Doctoral Programme of Higher Education of China (Grant No. 20100001120077). 


\section{REFERENCES}

Bergh P, Meis-Kindblom JM, Gherlinzoni F, Berlin O, Bacchini P, Bertoni F, Gunterberg B, Kindblom LG (1999) Synovial sarcoma: identification of low and high risk groups. Cancer 85(12): 2596-2607.

Brecht IB, Ferrari A, Int-Veen C, Schuck A, Mattke AC, Casanova M, Bisogno G, Carli M, Koscielniak E, Treuner J (2006) Grossly-resected synovial sarcoma treated by the German and Italian Pediatric Soft Tissue Sarcoma Cooperative Groups: discussion on the role of adjuvant therapies. Pediatr Blood Cancer 46(1): 11-17.

Cagle LA, Mirra JM, Storm FK, Roe DJ, Eilber FR (1987) Histologic features relating to prognosis in synovial sarcoma. Cancer 59(10): 1810-1814.

dos Santos NR, de Bruijn DR, van Kessel AG (2001) Molecular mechanisms underlying human synovial sarcoma development. Genes Chromosomes Cancer 30(1): 1-14.

Fletcher C, Unni K, Mertens F (2002) World Health Organization Classification of Tumours: Pathology and Genetics of Tumours of Soft Tissue and Bone. IARC Press: Lyon, France.

Guillou L, Benhattar J, Bonichon F, Gallagher G, Terrier P, Stauffer E, Somerhausen Nde S, Michels JJ, Jundt G, Vince DR, Taylor S, Genevay M, Collin F, Trassard M, Coindre JM (2004) Histologic grade, but not SYT-SSX fusion type, is an important prognostic factor in patients with synovial sarcoma: a multicenter, retrospective analysis. J Clin Oncol 22(20): 4040-4050.

Guillou L, Coindre J, Gallagher G, Terrier P, Gebhard S, de Saint Aubain Somerhausen N, Michels J, Jundt G, Vince DR, Collin F, Trassard M, Le Doussal V, Benhattar J (2001) Detection of the synovial sarcoma translocation $\mathrm{t}(\mathrm{X} ; 18)(\mathrm{SYT} ; \mathrm{SSX})$ in paraffin-embedded tissues using reverse transcriptase-polymerase chain reaction: a reliable and powerful diagnostic tool for pathologists. A molecular analysis of 221 mesenchymal tumors fixed in different fixatives. Hum Pathol 32(1): 105-112.

Guillou L, Coindre JM, Bonichon F, Nguyen BB, Terrier P, Collin F, Vilain MO, Mandard AM, Le Doussal V, Leroux A, Jacquemier J, Duplay H, Sastre-Garau X, Costa J (1997) Comparative study of the National Cancer Institute and French Federation of Cancer Centers Sarcoma Group grading systems in a population of 410 adult patients with soft tissue sarcoma. J Clin Oncol 15(1): 350-362.

Inagaki H, Nagasaka T, Otsuka T, Sugiura E, Nakashima N, Eimoto T (2000) Association of SYT-SSX fusion types with proliferative activity and prognosis in synovial sarcoma. Mod Pathol 13(5): 482-488.

Kawai A, Woodruff J, Healey JH, Brennan MF, Antonescu CR, Ladanyi M (1998) SYT-SSX gene fusion as a determinant of morphology and prognosis in synovial sarcoma. $N$ Engl J Med 338(3): 153-160.

Koković I, Bračko M, Golouh R, Ligtenberg M, Krieken HJJMv, Hudler P, Komel R (2004) Are there geographical differences in the frequency of SYT-SSX1 and SYT-SSX2 chimeric transcripts in synovial sarcoma? Cancer Detect Prev 28(4): 294-301.

Krall RA, Kostianovsky M, Patchefsky AS (1981) Synovial sarcoma: a clinical, pathological, and ultrastructural study of 26 cases supporting the recognition of a monophasic variant. Am J Surg Pathol 5(2): 137-151.

Kransdorf MJ (1995) Malignant soft-tissue tumors in a large referral population: distribution of diagnoses by age, sex, and location. AJR Am J Roentgenol 164(1): 129-134.

Ladanyi M (1995) The emerging molecular genetics of sarcoma translocations. Diagn Mol Pathol 4(3): 162-173.

Ladanyi M (2001) Fusions of the SYT and SSX genes in synovial sarcoma. Oncogene 20(40): 5755-5762.

Ladanyi M, Antonescu CR, Leung DH, Woodruff JM, Kawai A, Healey JH, Brennan MF, Bridge JA, Neff JR, Barr FG, Goldsmith JD, Brooks JS, Goldblum JR, Ali SZ, Shipley J, Cooper CS, Fisher C, Skytting B, Larsson O (2002) Impact of SYT-SSX fusion type on the clinical behavior of synovial sarcoma: a multi-institutional retrospective study of 243 patients. Cancer Res 62(1): 135-140.
Lewis JJ, Antonescu CR, Leung DH, Blumberg D, Healey JH, Woodruff JM, Brennan MF (2000) Synovial sarcoma: a multivariate analysis of prognostic factors in 112 patients with primary localized tumors of the extremity. J Clin Oncol 18(10): 2087-2094.

Lewis JJ, Brennan MF (1996) Soft tissue sarcomas. Curr Probl Surg 33(10): $817-872$.

Machen SK, Easley KA, Goldblum JR (1999) Synovial sarcoma of the extremities: a clinicopathologic study of 34 cases, including semiquantitative analysis of spindled, epithelial, and poorly differentiated areas. Am J Surg Pathol 23(3): 268-275.

Mezzelani A, Mariani L, Tamborini E, Agus V, Riva C, Lo Vullo S, Fabbri A, Stumbo M, Azzarelli A, Casali PG, Gronchi A, Sozzi G, Pierotti MA, Pilotti S (2001) SYT-SSX fusion genes and prognosis in synovial sarcoma. Br J Cancer 85(10): 1535-1539.

Mullen JR, Zagars GK (1994) Synovial sarcoma outcome following conservation surgery and radiotherapy. Radiother Oncol 33(1): 23-30.

Nilsson G, Skytting B, Xie Y, Brodin B, Perfekt R, Mandahl N, Lundeberg J, Uhlen M, Larsson O (1999) The SYT-SSX1 variant of synovial sarcoma is associated with a high rate of tumor cell proliferation and poor clinical outcome. Cancer Res 59(13): 3180-3184.

Panagopoulos I, Mertens F, Isaksson M, Limon J, Gustafson P, Skytting B, Akerman M, Sciot R, Dal Cin P, Samson I, Iliszko M, Ryoe J, Debiec-Rychter M, Szadowska A, Brosjo O, Larsson O, Rydholm A, Mandahl N (2001) Clinical impact of molecular and cytogenetic findings in synovial sarcoma. Genes Chromosomes Cancer 31(4): 362-372.

Peng C, Guo W, Yang Y, Zhao H (2008) Downregulation of SS18-SSX1 expression by small interfering RNA inhibits growth and induces apoptosis in human synovial sarcoma cell line HS-SY-II in vitro. Eur J Cancer Prev 17(5): 392-398.

Sobin L, Wittekind C (1997) International Union Against Cancer: TNM Classification of malignant tumours. 5th edn. WileyLiss: New York, NY, USA.

Spillane AJ, A'Hern R, Judson IR, Fisher C, Thomas JM (2000) Synovial sarcoma: a clinicopathologic, staging, and prognostic assessment. J Clin Oncol 18(22): 3794-3803.

Sun Y, Sun B, Wang J, Cai W, Zhao X, Zhang S, Hao X (2009) Prognostic implication of SYT-SSX fusion type and clinicopathological parameters for tumor-related death, recurrence, and metastasis in synovial sarcoma. Cancer Sci 100(6): 1018-1025.

Takenaka S, Naka N, Araki N, Hashimoto N, Ueda T, Yoshioka K, Yoshikawa H, Itoh K (2010) Downregulation of SS18-SSX1 expression in synovial sarcoma by small interfering RNA enhances the focal adhesion pathway and inhibits anchorage-independent growth in vitro and tumor growth in vivo. Int J Oncol 36(4): 823-831.

Takenaka S, Ueda T, Naka N, Araki N, Hashimoto N, Myoui A, Ozaki T, Nakayama T, Toguchida J, Tanaka K, Iwamoto Y, Matsumine A, Uchida A, Ieguchi M, Kaya M, Wada T, Baba I, Kudawara I, Aoki Y, Yoshikawa H (2008) Prognostic implication of SYT-SSX fusion type in synovial sarcoma: a multi-institutional retrospective analysis in Japan. Oncol Rep 19(2): 467-476.

Trassard M, Le Doussal V, Hacene K, Terrier P, Ranchere D, Guillou L, Fiche M, Collin F, Vilain MO, Bertrand G, Jacquemier J, Sastre-Garau X, Bui NB, Bonichon F, Coindre JM (2001) Prognostic factors in localized primary synovial sarcoma: a multicenter study of 128 adult patients. J Clin Oncol 19(2): 525-534.

van de Rijn M, Barr FG, Collins MH, Xiong QB, Fisher C (1999) Absence of SYT-SSX fusion products in soft tissue tumors other than synovial sarcoma. Am J Clin Pathol 112(1): 43-49.

This work is published under the standard license to publish agreement. After 12 months the work will become freely available and the license terms will switch to a Creative Commons AttributionNonCommercial-Share Alike 3.0 Unported License. 